\title{
Bacteria associated with tunicate, Polycarpa aurata, from Lease Sea, Maluku, Indonesia exhibiting anti-multidrug resistant bacteria
}

\author{
DIAH AYUNINGRUM ${ }^{1,5}$, RHESI KRISTIANA ${ }^{1}$, AYUNDA AINUN NISA ${ }^{2}$, SEPTHY KUSUMA RADJASA ${ }^{2}$, \\ SAKTI IMAM MUCHLISSIN ${ }^{2,4}$, OCKY KARNA RADJASA ${ }^{2,3}$, AGUS SABDONO ${ }^{2}$, AGUS TRIANTO A, $^{2, \bullet}$ \\ ${ }^{1}$ Department of Coastal Resource Management, Faculty of Fisheries and Marine Science, Universitas Diponegoro. Jl. Prof. Soedharto SH, Semarang \\ 50275, Central Java, Indonesia \\ ${ }^{2}$ Department of Marine Science, Faculty of Fisheries and Marine Science, Universitas Diponegoro. J1. Prof. Soedarto, SH, Tembalang, Semarang 50275 , \\ Central Java, Indonesia. Tel.: +62-24-7474698, Fax.: +62-24-7474698, `email: agustrianto.undip@ gmail.com. \\ ${ }^{3}$ Directorate of Research and Community Services, Ministry of Research, Technology and Higher Education. D Building, Jl. Jenderal Sudirman Pintu \\ Satu, Senayan, Jakarta Pusat 10279, Indonesia \\ ${ }^{4}$ Tropical Marine Biotechnology Laboratory, Universitas Diponegoro Jl. Lingkar Utara Undip, Semarang 50275, Central Java, Indonesia \\ ${ }^{1}$ Department of Aquatic Resource Management, Faculty of Fisheries and Marine Science, Universitas Diponegoro. Jl. Prof. Soedharto SH, Semarang \\ 50275, Central Java, Indonesia
}

Manuscript received: 30 January 2019. Revision accepted: 10 March 2019.

\begin{abstract}
Ayuningrum D, Kristiana R, Nisa AA, Radjasa SK, Muchlissin SI, Radjasa OK, Sabdono A, Trianto A. 2019. Bacteria associated with tunicate, Polycarpa aurata, from Lease Sea, Maluku, Indonesia exhibiting anti-multidrug resistant bacteria. Biodiversitas 20: 956-964. Tunicate is a rich secondary metabolites producer with various biological activities whether as an original producer or produced by the associated microorganisms. In this study, a total of 11 tunicate specimens were identified as Polycarpa aurata with four color variations based on morphological characteristic and COI gene identification and BLAST analysis. The $P$. aurata associated-bacteria were isolated and tested for antimicrobial activity against multi-drug resistant (MDR) bacteria. A total of 86 axenic isolates were successfully purified. Furthermore, nine isolates $(10.5 \%)$ exhibited antibacterial activity on preliminary screening. Nine prospective isolates were fermented in respective medium (Zobell 2216, modified M1 or modified ISP2 media) then extracted using ethyl acetate. The ethyl acetate extracts from liquid fermentation were tested against MDR Escherichia coli, MDR Bacillus cereus, Methicillin-Resistant Staphylococcus aureus (MRSA) and Methicillin-Sensitive and Staphylococcus aureus (MSSA). As a result, seven isolates $(8.1 \%)$ still retained the activity at the extract concentration $150 \mu \mathrm{g} / \mathrm{disk}$. Molecular analysis based on $16 \mathrm{~S}$ rDNA sequencing revealed the most active isolates, TSB 47, TSC 10 and TSB 34 identified as Bacillus tropicus, Vibrio alginolyticus and Virgibacillus massiliensis, with BLAST homology $99 \%$.
\end{abstract}

Keywords: Polycarpa aurata, associated bacteria, anti-multidrug resistant, tunic-color variation

\section{INTRODUCTION}

Benthic organisms including tunicate, mostly produce bioactive metabolites to give respond towards ecological stresses, i.e., food and space competition, micro or macrofouling organisms, and predator/invader deterrence (Lambert 2005). Tunicate is well known as a potential source of bioactive compounds that originally used as a chemical defense (Paul et al. 1990). Besides, some of these metabolites are toxic to cells and are potential to be used as pharmaceuticals (Kim et al. 2015). It is noted that the members of Aplousobranchia are the best source of the natural product since $80 \%$ of the tunicates-original natural product were isolated from Clavelinids, Polyclinids, Polycitorids, and Didemnids (Ali and Tamilselvi 2016).

Thousands of natural products have been isolated from ascidians (Schmidt et al. 2012), which mostly are nitrogenous compounds have various biological activities such as antimicrobial, antineoplastic, antitumor, antifouling, antioxidant, anti-inflammatory, plant growth regulatory activity, deterrent activity, insect control, wound healing activity, hepatic productive activity, immune stimulating activity, etc (Fattoruso et al. 2012; Kim 2015).
Ecteinascidin 743 (Sakai et al. 1992), Didemnin B (Anksietty et al. 2013), Aplidin (Bertanha et al. 2014), Diazonamide A-E (Lindquistl et al. 1991), Vitilevuamide (Edler et al. 2002), and Lissoclibadins (Nakazawa et al. 2007) are some of the compounds successfully isolated from tunicates that performed cytotoxic activity against some cancer cell line, i.e. soft tissue sarcoma, renal carcinomas, osteosarcoma, breast cancer, human colon cancer, as well as antimicrobial activity, etc.

Direct evidence has confirmed that $\sim 8 \%$ of natural products from ascidians are produced by symbiotic microorganisms, among them, polyketides and alkaloid compounds represent $43.3 \%$ of the total number with the highest percentage $(31.3 \%)$ function as antimicrobial (Chen et al. 2018). Some compounds exhibited antitumor potential by in vivo study, and several promising drugs have been used in preclinical evaluation and clinical trials. Microorganisms are a promising source of bioactive compounds, and the discovery of new isolates is vital for new or more active compounds (Penesyan et al. 2010).

The development of new families of antibiotics throughout the 1950s and 1960s and of modifications of these molecules through the 1970s and 1980s conquer the 
problem of infection caused by bacteria (WHO 2014). By the time, inappropriate use of antibiotics (overuse or lack in use) emerged the bacteria resistant to antibiotics. The bacteria which become insensitive to more than three class of antimicrobials were known as multi-drug resistant bacteria (MDR). The selection and spread of multi-drug resistant (MDR) bacteria caused by extensively misused of antibiotics in many sectors such as hospitals and animal husbandry (Magiorakos et al. 2012). By the $21^{\text {st }}$ century, the new drugs are running, and the development of new antimicrobials are weak (CDC 2013). Resistance costs money, livelihoods and live. It has recently been described as a threat to global stability and national security. The utmost infectious agent, including in Indonesia, should be concerned are Escherichia coli and Staphylococcus aureus. $E$. coli which having the high reported resistance to fluoroquinolones lead to limitation of antimicrobials to treat infection caused by it, such as urinary tract infections (Severin et al. 2012). High rates of Methicillin-Resistant Staphylococcus aureus (MRSA) imply that treatment for severe $S$. aureus infections, such as common skin and wound infections, must rely on second-line drugs in many countries (Lestari et al. 2008). Thus, it is essential to look for another source of the novel bioactive compound, such as bacteria associated with tunicate. Therefore, in this study, an initial screening project to investigate the potent anti-multidrug resistant activity of tunicate-associated bacteria is reported.

\section{MATERIALS AND METHODS}

\section{Specimen collection}

The specimens were collected at the Lease Sea, Maluku, Indonesia on September 2018. All specimens were collected at depth 8-17 m by scuba diving. The specimens were documented and labeled before stored in a sterile plastic zip lock for further processing.

\section{Specimen identification}

The specimens were identified morphologically using guidance books (Kott 2004; Ali and Tamilselvi 2016). Molecular identification of tunicates was using gene COI amplification. The DNA extraction was performed using the DNA extraction kit from Zymo Research following the protocol from the supplier. PCR was performed in $25 \mu \mathrm{L}$ volume consist of $12.5 \mu \mathrm{L}$ Lucigen master mix, forward primer $2.5 \mu \mathrm{L}$, reverse primer $2.5 \mu \mathrm{L}, \mathrm{DDH}_{2} \mathrm{O} 6.5 \mu \mathrm{L}$, and DNA template $1 \mu \mathrm{L}$. Primers used in this research were universal COI primer LCO1490 5' GGT CAA CAA ATC ATA AAG ATA TTG G 3'and HCO2198 5' TAA ACT TCA GGG TGA CCA AAA AAT CA 3' (Folmer et al. 1994), and if it did not work another primer used was Tun forward 5, TCG ACT AAT CAT AAA GAT ATT AG ${ }^{-}$', and Tun_reverse 5' AAC TTG TAT TTA AAT TAC GAT C 3' (Stefaniak et al. 2009). PCR reaction was conducted in Biorad T100 with the following program: (1) for primer LCO1490 and $\mathrm{HCO} 2198$; initial incubation at 94 ${ }^{\circ} \mathrm{C}$ for 1 minute, followed by 5 cycles of $94{ }^{\circ} \mathrm{C}$ for 40 second, $45{ }^{\circ} \mathrm{C}$ for 40 second and $72{ }^{\circ} \mathrm{C}$ for 60 second; 35 cycles of $94{ }^{\circ} \mathrm{C}$ for 40 second, $51{ }^{\circ} \mathrm{C}$ for 40 second, $72{ }^{\circ} \mathrm{C}$ for 60 second; and a final extension step of $72{ }^{\circ} \mathrm{C}$ for 5 minute (Dias et al. 2016). (2) for primer tun_forward and tun reverse; initial denaturation at $94{ }^{\circ} \mathrm{C}$ for 1 minute, followed by 60 cycles of denaturation at $94{ }^{\circ} \mathrm{C}$ for 10 seconds, annealing at $50{ }^{\circ} \mathrm{C}$ for 30 seconds, elongation at $72{ }^{\circ} \mathrm{C}$ for 50 second and final elongation at $72{ }^{\circ} \mathrm{C}$ for 10 minutes (Stefaniak et al. 2009). PCR products were examined on a $1 \%$ agarose gel and the result was visualized using UVIDoc HD5 (UVITEC Cambridge). The good PCR products were sent to the $1^{\text {st }}$ base for further sequencing.

\section{Isolation of the associated bacteria}

The tunicate-associated bacteria were isolated using serial dilution method (Benson 2001). The homogenized tunicate tissue was serially diluted and spread $(30 \mu \mathrm{L})$ onto different media (M1, ISP2, and Zobell 2216 Himedia). The plates were all incubated for two days for fast-growing bacteria and seven days for slow-growing bacteria at room temperature $\left(29 \pm 2^{\circ} \mathrm{C}\right)$. The purification process was based on the morphological feature using the streak method (Benson 2001). The process was continued until the axenic culture obtained. The bacterial isolates were named according to the tunicate codes where they isolated.

\section{Screening for anti-MDR activity}

The anti-MDR potential of the isolates was investigated using the agar plug method. The pathogens were obtained from the Medical Microbiology Laboratory Dr. Kariadi Hospital, Semarang, Central Java, Indonesia. The isolates were grown for 3-4 days for optimal metabolite production on respective medium (Zobell 2216 Himedia, modified M1, modified ISP2 medium). The pathogens were grown for overnight, then measured for $0.5 \mathrm{Mc}$ Farland $\left(10^{8} \mathrm{CFU}\right)$ and swapped on to soft strength Nutrient Agar (NA) medium. Agar blocks were taken from isolates cultures and were placed on to it. The bacterial agonist for screening were human pathogens, i.e. Methicillin-Resistant Staphylococcus aureus (MRSA), Methicillin-Sensitive Staphylococcus aureus (MSSA), Multidrug-Resistant (MDR) Bacillus cereus, MDR Escherichia coli. Plates were incubated at $37{ }^{\circ} \mathrm{C}$ for overnight, after initial incubation of $1 \mathrm{~h}$ at $4^{\circ} \mathrm{C}$. The inhibition zone was measured in the next following day at $16 \mathrm{~h}, 20 \mathrm{~h}$, and $24 \mathrm{~h}$.

\section{Gram staining and potassium hydroxide test}

The gram staining test was performed to identify the isolates belong to gram-positive or gram-negative bacteria. The method used was according to Benson (2001), prepared four solution Gram A (crystal violet), gram B (Iodine), gram C (decolorizer) and gram D (safranin). All solutions were provided from Gram Stain-Kit Himedia ${ }^{\circledR}$. Confirmation of gram's staining was using Potassium Hydroxide $(\mathrm{KOH})$ test. The method used was 3\% $\mathrm{KOH}$ dissolved in demineralized water (Halaebian et al. 1981; Gravenitz and Bucher 1983).

\section{$16 S$ rDNA identification}

DNA of the bacteria were extracted using a modified saponin method (Ayuningrum et al. 2017). The obtained 
DNA sample was examined using NanoDrop 2000 spectrophotometer (Thermo Scientific, USA) to get information about the concentration and purity.

The bacterial identification was performed using universal gene primer 27F 5'AGAGTTTGATCMTGGCTCAG-3 and 1492 R 5'GGTTACCTTGTTACGACTT-3' (Weisburg et al. 1991). PCR Reaction was conducted in an Thermal Cycler (BIORAD) T100 using optimization consist of initial denaturation at $95{ }^{\circ} \mathrm{C}$ for 3 minutes, then followed by 30 cycles of denaturation at $95^{\circ} \mathrm{C}$ for $1 \mathrm{~min}$ each cycle, annealing at $53.9^{\circ} \mathrm{C}$ for 1 minutes, extension at $72^{\circ} \mathrm{C}$ for 1 minutes, and followed by final extension at $72^{\circ} \mathrm{C}$ for 7 minutes (Ayuningrum et al. 2017). PCR products were examined using agarose $1 \%$ gel electrophoresis, and the result was visualized by using UVIDoc HD5 (UVITEC Cambridge, UK).

\section{Metabolite extraction}

The prospective isolates were transferred from plate to $150 \mathrm{~mL}$ Erlenmeyer flask containing $50 \mathrm{~mL}$ respective medium, then incubated in room temperature $29 \pm 2{ }^{\circ} \mathrm{C}$ with $110 \mathrm{rpm}$ for 24 hours as pre-culture. Then, $1 \%(\mathrm{v} / \mathrm{v})$ from pre-culture was transferred to $500 \mathrm{~mL}$ Erlenmeyer flask containing $200 \mathrm{~mL}$ of the same medium. The culture was fermented for four days with $110 \mathrm{rpm}$ in the shaker. The liquid medium was extracted using ethyl acetate (1:1) after incubation periods, and the mixture was shaken thoroughly for 24 hours. The organic phase was separated from the water phase using a separatory funnel, then concentrated using rotary evaporator until the dried extract obtained.

\section{Antimicrobial assay of bacterial extract}

The Mueller Hinton Agar were prepared for the bioassay according to Balouiri et al. (2016), while the pathogens (MDR E. coli, MDR Bacillus cereus, MSSA and MRSA) were grown overnight on Nutrient Broth media at $37^{\circ} \mathrm{C}$. The pathogens were adjusted to $0.5 \mathrm{McFarland}$ then swapped onto MHA media. As much as $15 \mu \mathrm{L}$ of the ethyl acetate extract $(150 \mu \mathrm{g} / \mathrm{disk})$ was added to a paper disk that then placed on the agar plate. The plates were incubated in $37{ }^{\circ} \mathrm{C}$ for overnight. The clear zones that appear around the paper disk were recorded using Vernier caliper.

\section{RESULTS AND DISCUSSION}

\section{Identification of the tunicates}

The underwater photographs of the tunicates specimen were provided in Figure 1. Specimens 18-SM-S-12 and 18SM-T-4 were identified as Polycarpa aurata based on COI gene sequences with $95 \%$ similarity. The rest of tunicate specimens (18-SM-S-25, 18-SM-T-25, 18-SM-T-14, 18SM-T-19, 18-SM-T-22, 18-SM-T-1, 18-SM-T-21, 18-SMT-20 and 18-SM-T-3) were confirmed as $P$. aurata based on morphological appearance.

The collected $P$. aurata has characteristics; 5 to $6 \mathrm{~cm}$ height and 2 to $3 \mathrm{~cm}$ width with urn body shape, with hollow and two siphons at the top and the other side. The color of the tunic are varied, but they have the main four colors; blue, orange, white and mixed (Figure 2). Although all specimens have different tunic color, they shared the same blue line color which separates the compartment in their tunic and gives shape in their tunic. The tunic line color can become bluish-purple in $P$. aurata which have orange and mixed tunic color. Meanwhile, for blue and white tunic color, they also have blue tunic line. Specimens 18-SMT-4 and 18-SM-S-12 had blue color with blue lines on their body. The other specimens 18-SM-T-1, 18-SM-T20, 18-SM-T-25 and 18-SM-T-14 had two dominant colors which were white and blue with blue lines on the tunic. The rest of the specimens 18-SM-T-19, 18-SM-T-22, 18-SM-T$21,18-\mathrm{SM}-\mathrm{T}-3$ and 18-SM-S-25 had orange as a dominant color, and some white spots in their tunic as well as the blue lines on the tunics.

The tunic color variation is probably regulated by multiple allele inheritances with codominance. Multiple alleles are the condition of a gene which has more than one alternative form that affects the phenotype. Meanwhile, codominance means the two alleles or more each affect the phenotype in separate, distinguishable ways (Campbell et al. 2009). In this research, we found that the frequency of phenotype blue, orange, mixed and white were 2, 2, 6 and 1. Thus, we assumed that there were minimal three alleles in single gene $\mathrm{C}^{\mathrm{B}}, \mathrm{C}^{\mathrm{O}}$, and c. The dominant allele was $\mathrm{C}^{\mathrm{B}}$ ( $\mathrm{C}$ for color and $\mathrm{B}$ for Blue) and $\mathrm{C}^{\mathrm{O}}(\mathrm{C}$ for color and $\mathrm{O}$ for orange). Then, the $\mathrm{c}$ was for recessive allele. The expression of phenotype was following these rules; (i) when there was $\mathrm{C}^{\mathrm{B}}$ then the tunic color will be blue, (ii) but if there was $\mathrm{C}^{\mathrm{O}}$, then the tunic will be orange. Furthermore, (iii) if both alleles come together as $\mathrm{C}^{\mathrm{B}} \mathrm{C}^{\mathrm{O}}$ then the tunic color will be mixed blue-orange. On the other hand, (4) if both dominant alleles did not present in the genes mean the tunic will be white. The explanation of the color variation inheritance was in Table 1. The frequency of white tunic $P$. aurata was the lowest because it was recessive. The highest phenotype frequency was the intermediate with mixed tunic color (6 specimens out of 11 specimens).

The molecular identification based on BLAST homology and a phylogenetic tree was shown in Table 2 and Figure 3. P. aurata belongs to the genus Polycarpa, subfamily Styelinae, family Styelidae, Subordo Stolidobranchiata, Ordo Pleurogona, Class Asidiacea. P. aurata characteristics both siphons have four-lobed, usually four folds on each side of the branchial sac (Shenkar et al. 2019).

Some species from genus Polycarpa was known as secondary metabolites producers, such as polycarpamine B from $P$. auzata (Lindquist and Fenical 1990), polycarpaurines A-C (Wang et al. 2007) and polycarpathiamines A-B (Pham et al. 2013) from Indonesian $P$. aurata. Another compound structurally related to zorrimidazolone have been isolated from $P$. clavata and P. aurata (Aiello et al. 2011). Furthermore, the guanidinic derivatives of methoxyphenols from ascidian of the genus Polycarpa have been reported (Wessels et al. 2001). 

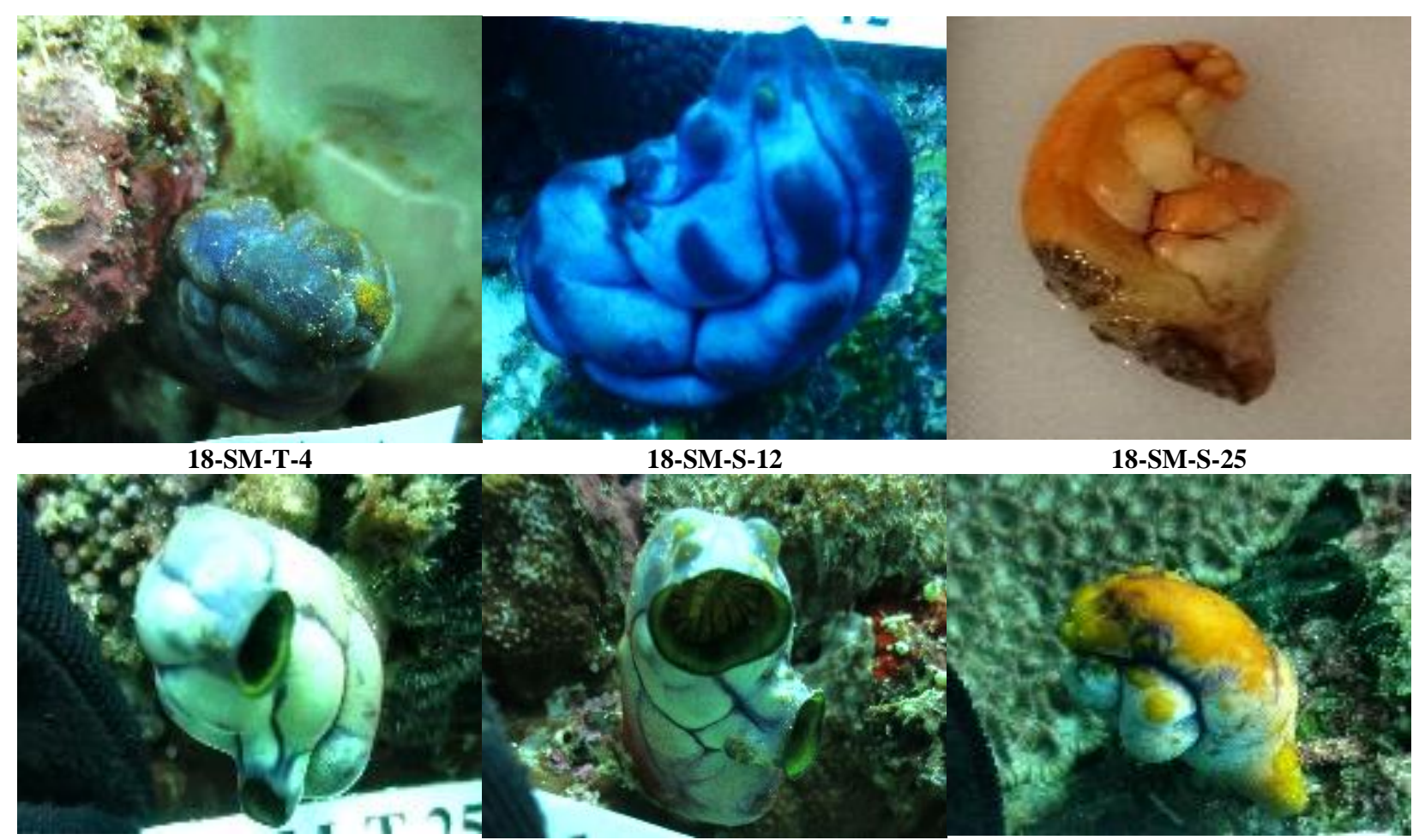

18-SM-S-25
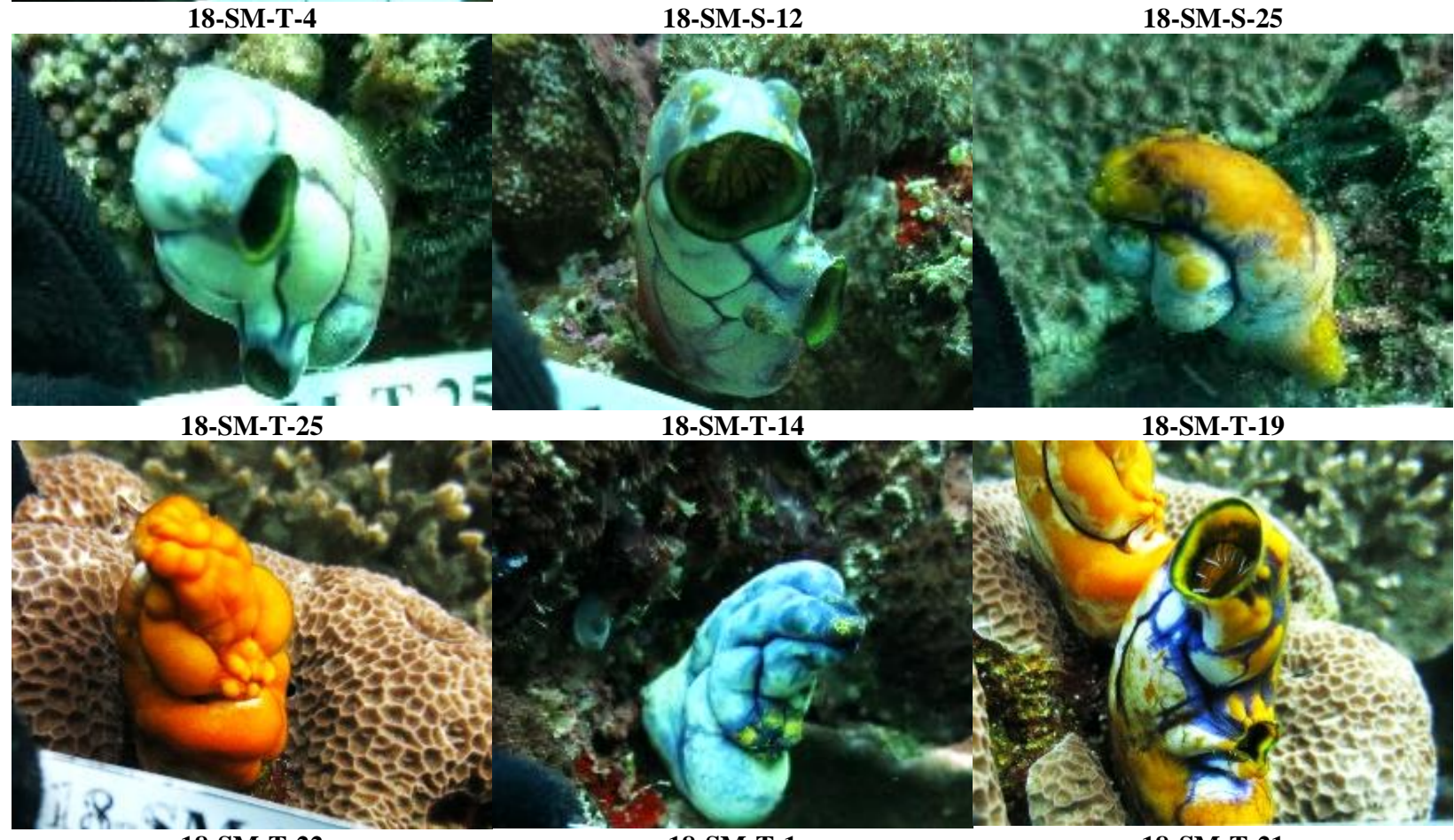

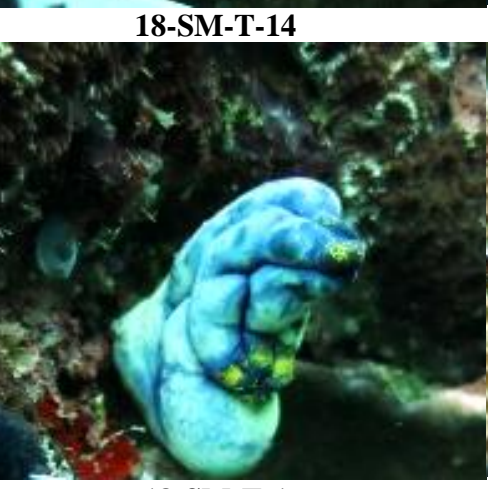

18-SM-T-1

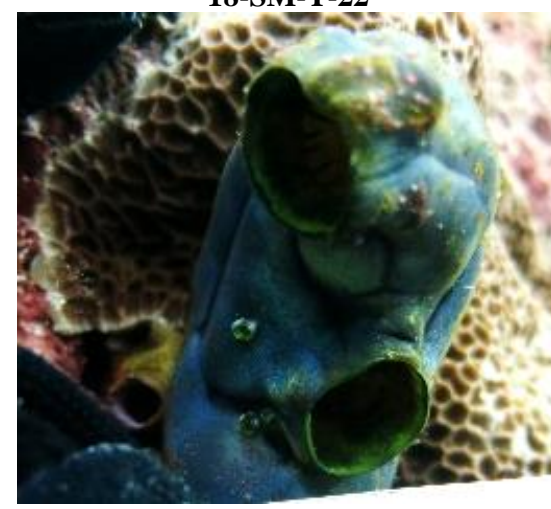

18-SM-T-20

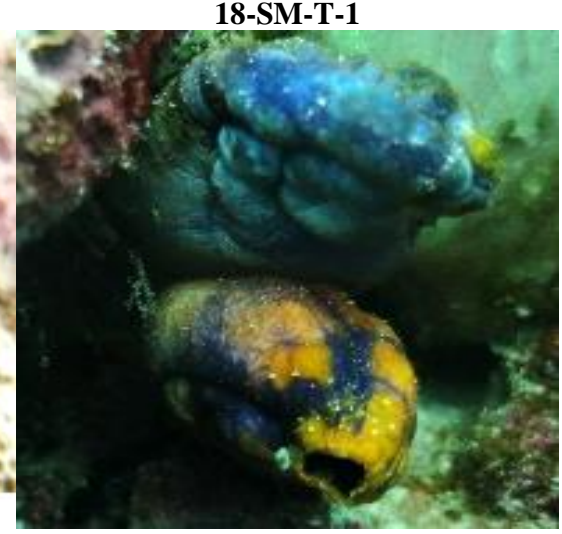

18-SM-T-3

Figure 1. Documentation of Polycarpa aurata underwater and outside water. $\mathrm{Bar}=3 \mathrm{~cm}$

\section{The abundance of tunicate-associated bacteria}

As many as 86 axenic isolates were successfully isolated from $11 \mathrm{P}$. aurata specimens. The modified M1 medium was giving the best result for isolating the associated bacteria (43\%) compared to the medium readyto-use Zobell 2216 Himedia $(38.4 \%)$ and modified ISP2 medium (18.6\%). Furthermore, the modified M1 medium also gives the best result for primary screening against MDR bacteria (56\%) and crude extract activity (57\%). Meanwhile medium ready-to-use Zobell 2216 Himedia give the least antimicrobial activity on primary screening $(11 \%)$ and for crude extract activity (0\%) (Figure 4). 
Table 1. Multiple alleles inheritance for tunic color of Polycarpa aurata

\begin{tabular}{lll}
\hline Genotype & Phenotype & Specimen \\
\hline CBCB or CBc & Blue & 18-SM-S-12, 18-SM-T-4 \\
COCO or COc & Orange & 18-SM-T-22, 18-SM-S-25 \\
CBCO & Mixed & 18-SM-T-1, 18-SM-T-3, 18-SM-T- \\
& blue-orange & 14, 18-S-M-T-19, 18-SM-T-20, 18- \\
& & SM-T-21 \\
cc & White & 18-SM-T-25 \\
\hline
\end{tabular}

Table 2. BLAST Homology result of Tunicate specimen

\begin{tabular}{llcc}
\hline Specimen & Closest relativity & Ident & $\begin{array}{c}\text { Accession } \\
\text { number }\end{array}$ \\
\hline 18-SMS-12 & Polycarpa aurata & $95 \%$ & LC455705 \\
18-SMT-4 & Polycarpa aurata & $95 \%$ & LC455707 \\
\hline
\end{tabular}

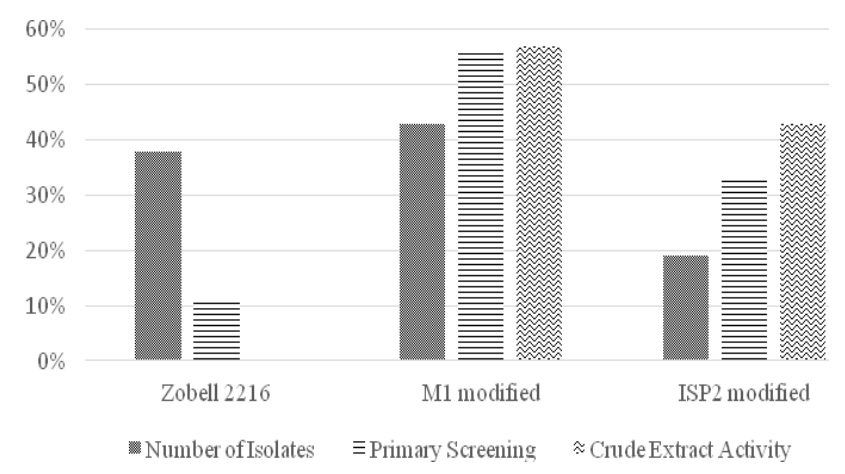

Figure 4. The number of bacteria isolates, primary screening for anti-MDR activity and secondary screening (crude extract activity) from Polycarpa aurata-associated bacteria in different media. M1 modified medium showed high abundance as well as high antimicrobial activity in the solid or crude extract.

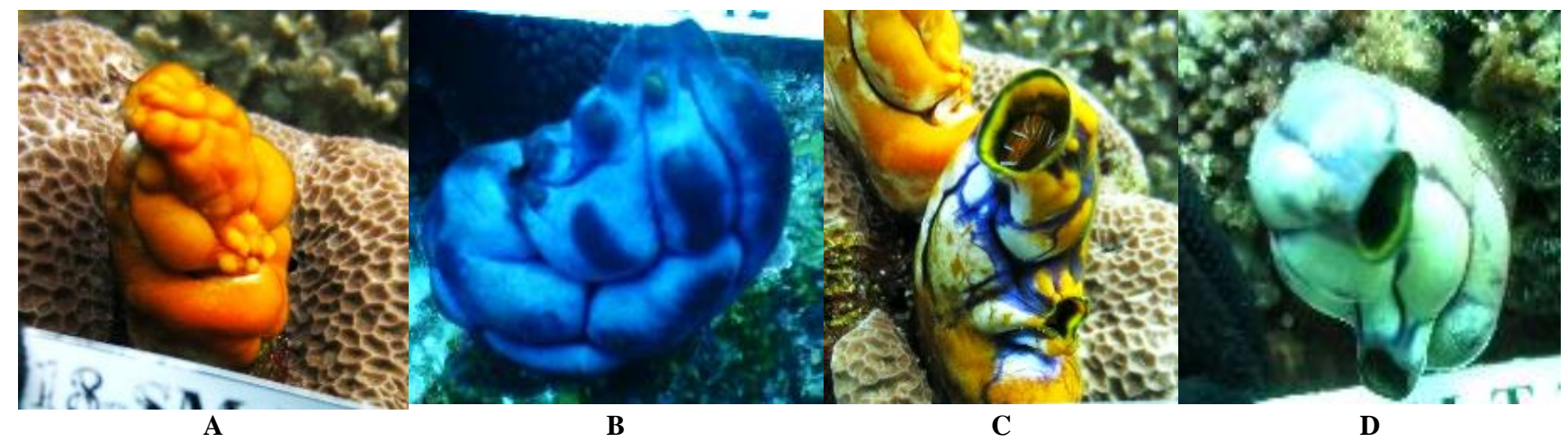

Figure 2. The phenotype of Polycarpa aurata tunic color. A. Orange tunic, B. Blue tunic, C. White tunic, D. Mixed tunic

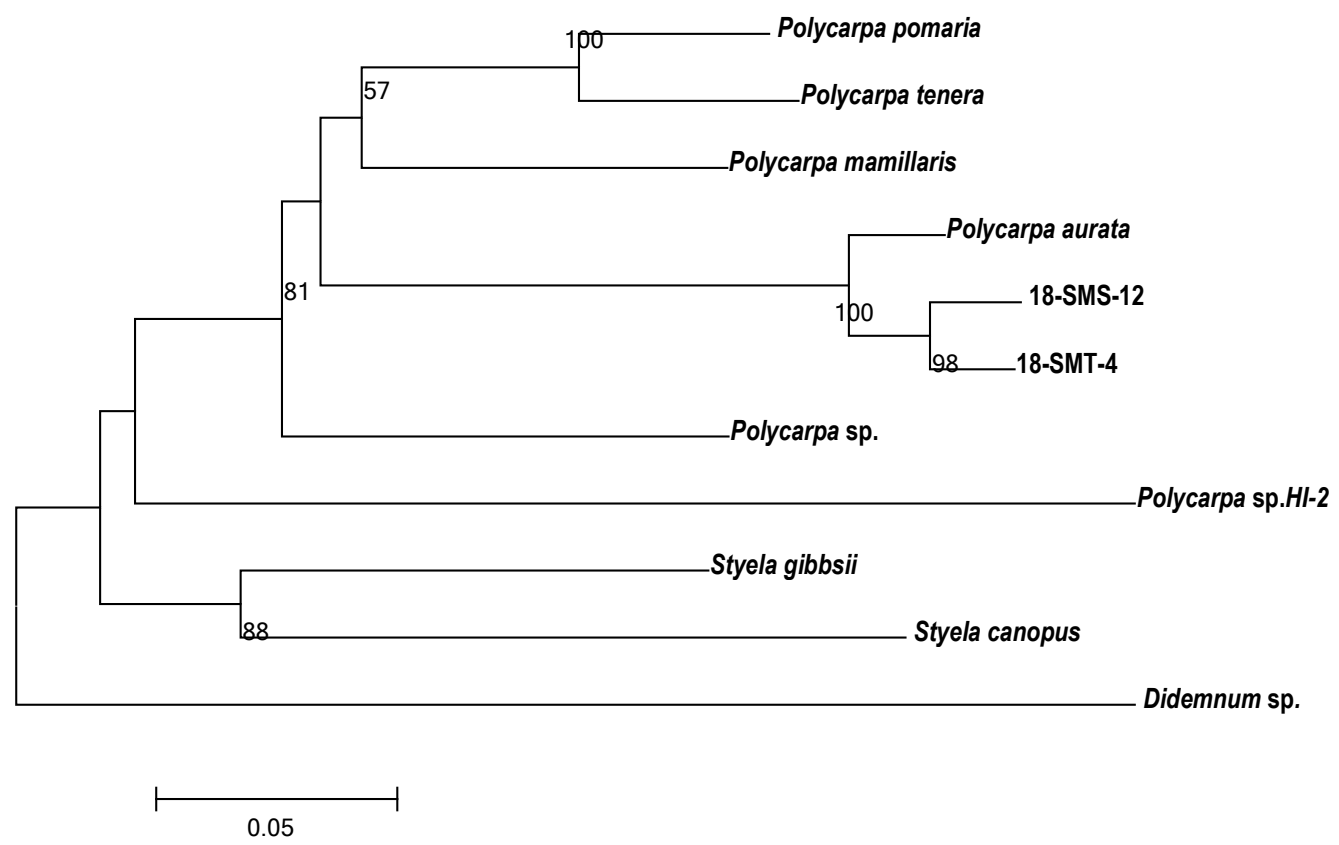

Figure 3. Phylogenetic tree of specimens 18-SMS-12 and 18-SMT-4 
Many researchers reported that marine invertebrate associated-bacteria have potential as antibacterial, i.e. from gorgonia (Kristiana et al. 2017), sponge (Asagabaldan et al. 2017), and hard coral (Ayuningrum et al. 2017; Sibero et al. 2018). This study suggested that tunicate-associated bacteria are also potential for bioprospecting of bioactive compounds.

\section{Antimicrobial activity}

A total of 9 isolates $(10.5 \%)$ exhibited antibacterial activity against human MDR pathogen bacteria. Those active isolates were TSB 47, TSB 46, TSC 10, TSB 34, TSC 12, TSB 02, TSC 51, TSA 61 and TSB 03. The result of gram staining indicated that eight isolates of the prospective bacteria were gram-positive bacteria, whereas TSC 10 was an only gram-negative bacterium. According to morphological characterization under a microscope, the isolate TSB 47 and TSB 46 were having similar characteristics including shape and gram staining. Both isolates also from the same specimen 18-SMT-3. Therefore, only one strain TSB 47 was being molecularly identified. The isolate TSB 34 had $99 \%$ similarity to Virgibacillus massiliensis, TSB 47 had $99 \%$ similarity to Bacillus tropicus, while TSC 10 had $99 \%$ similarity to Vibrio alginolyticus according to $16 \mathrm{~S}$ rDNA comparison. The phylogenetic tree of three promising isolates was shown in Figure 5.

Vibrio massiliensis TSB 34 was one of Polycarpaassociated bacterium found in this research. It is a grampositive, endospore-forming, rod-shaped and moderately halophilic, the same as described in Rosenberg et al. (2014), it belongs to phylum Firmicutes, Class Bacilli, Order Bacillales, Family Bacillaceae, and Genus Virgibacillus. Another Bacillaceae found in this research was B. tropicus TSB 47. Another Bacillaceae which found in this research was Bacillus tropicus TSB 47. Meanwhile, isolate TSC 10 was belong to phylum Proteobacteria, Class Gammaproteobacteria, Order Vibrionales, Family Vibrionaceae, and Genus Vibrio (Rosenberg et al. 2014).

\section{Crude extract activity}

The best activity of the crude extract concentration 150 $\mu \mathrm{g} /$ disk was against the gram-positive pathogen, MDR Bacillus cereus, followed by MSSA, MDR E. coli, and last MRSA. The isolate $B$. tropicus TSB 47 was able to inhibit MDR B. cereus with $28 \mathrm{~mm}$ zone of inhibition (ZOI), followed by isolate TSB 46 (ZOI $23.54 \mathrm{~mm}$ ), $V$. massiliensis TSB 34 (ZOI $16.34 \mathrm{~mm}$ ) and last TSB 02 (ZOI $10.00 \mathrm{~mm}$ ). Meanwhile, the best activity against gram-negative pathogen, MDR $E$. coli, was also from isolating B. tropicus TSB 47 with ZOI $17.46 \mathrm{~mm}$, followed by TSB 46 (ZOI $10.90 \mathrm{MM}$ ), and the least from $V$. massiliensis TSB 34 (ZOI 7.90mm). The two isolates (TSA 61 and TSB 03) were losing anti-MDR activity in liquid culture by not forming any inhibition zone against all pathogen tested (figure 6).

The family Bacillaceae showed a high percentage of antimicrobial activity against gram-positive and gramnegative bacteria in previous studies (Arunachalam and
Appadorai 2013; Ayuningrum et al. 2017). Bacilli produce a wide range of natural products, including lipopeptides, polypeptides, macrolactams, fatty acids, polyketides, and isocoumarins, with a series of bioactivities (Mondol et al. 2013; Mohan et al. 2016). On the other hand, a gramnegative bacterium, Vibrio algynoliticus TSC 10 belonged to family Vibrionaceace was isolated from the tunicate specimen 18-SMT-14. The secondary metabolite compounds from this family have been reported such as andrimid, cycloprodigiosin, holomycin and prodgiosin (Mansson et al. 2011).

As the crude extract itself found with potential antiMDR activity, testing the individual compounds from the crude extract of $V$. massiliensis TSB 34, B. tropicus TSB 47 and $V$. algynoliticus TSC 10 will ensure the structural elucidation of a novel compound with higher potential of anti-MDR activity. In the present investigation, the metabolites produced by the marine bacteria associated with the tunicate $P$. aurata was evaluated for antimultidrug resistant activity. This research pointed out the potential of metabolites produced in combating the MDR E. coli, MDR B. cereus, MRSA and MSSA. The antimultidrug resistant activity of bacterial metabolites over MDR B. cereus was above $28 \mathrm{~mm}$ zone of inhibition at a concentration of $150 \mu \mathrm{g} /$ disk. Separation of individual compounds is underway to find out the exact compound responsible for its potential anti-multidrug resistant activity. As most of the tunicate-associated microorganisms derived metabolites are still not utilized at a great level for the development of drugs as well as for the infection caused by a bacterial pathogen. The present report on the bioprospecting of the bacteria associated with the tunicate $P$. aurata will lead to the discovery of bioactive compound.

In conclusion, a total of 11 specimens of $P$. aurata with four different color variation have been collected and identified morphologically and molecularly. Among those specimens, a classical method for drug discovery started from the isolation of the bacteria until crude extract screening was performed. Molecular identification and phylogenetic analysis revealed the most active isolates belonged to both grams positive (Virgibacillus massiliensis TSB 34 and Bacillus tropicus TSB 47) and negative (Vibrio alginolyticus TSC 10). Thus, P. aurata associated bacteria can be regarded as a new promising resource for the discovery of bioactive compounds function as antiMDR.

\section{ACKNOWLEDGEMENTS}

This project was supported by the grant from the Ministry of Research, Technology and Higher Education, Indonesia under the scheme Master Program of Education Leading to Doctoral Degree for Excellent Graduates (PMDSU) No. 102-04/UN7.P4.3/PP/2018. The specimens were collected legally by the permission from the official of Maluku Province, Indonesia. Those specimens are not listed in IUCN or CITES. 


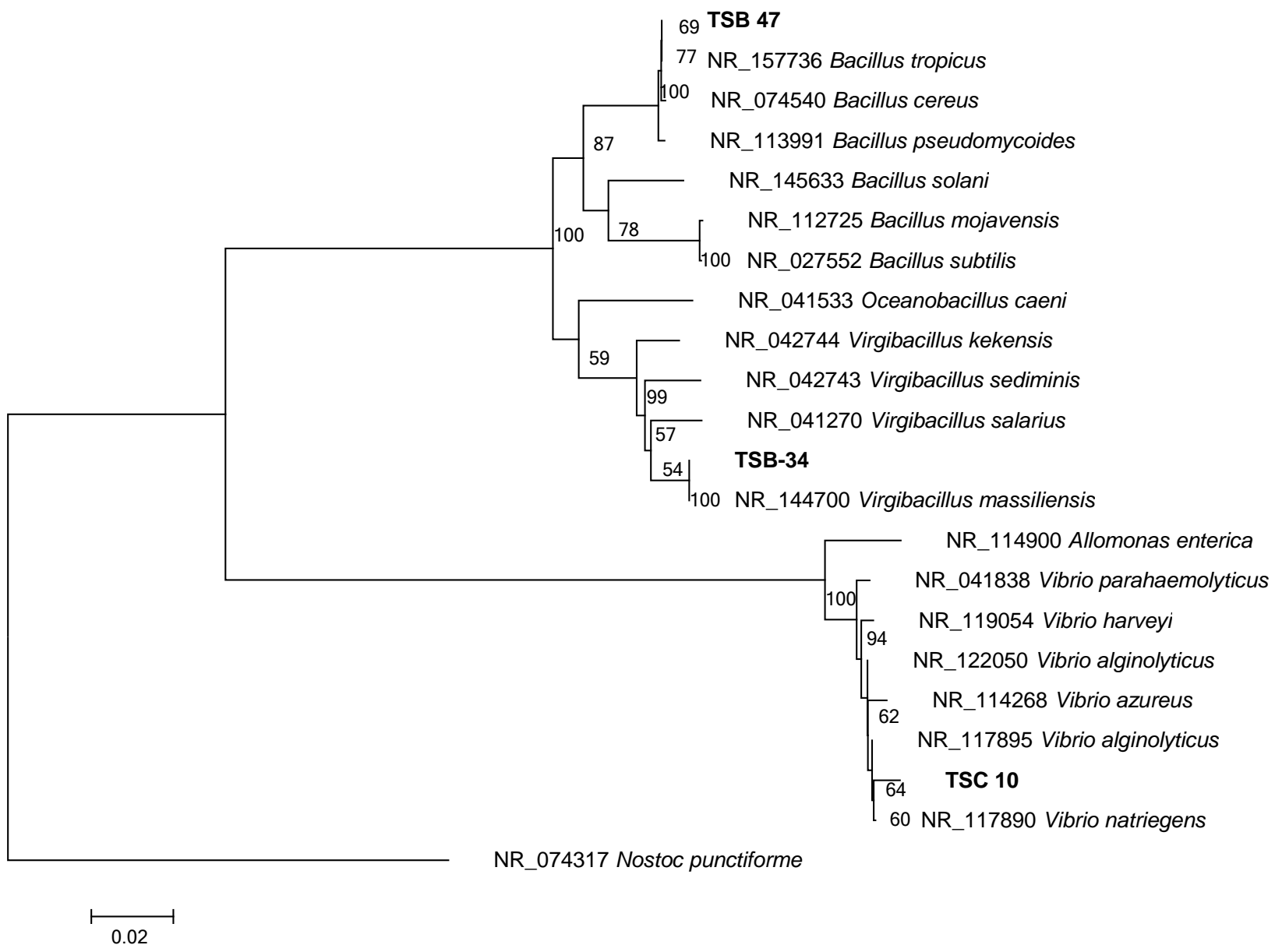

Figure 5. Phylogenetic tree of TSB 34, TSB 47 and TSC 10

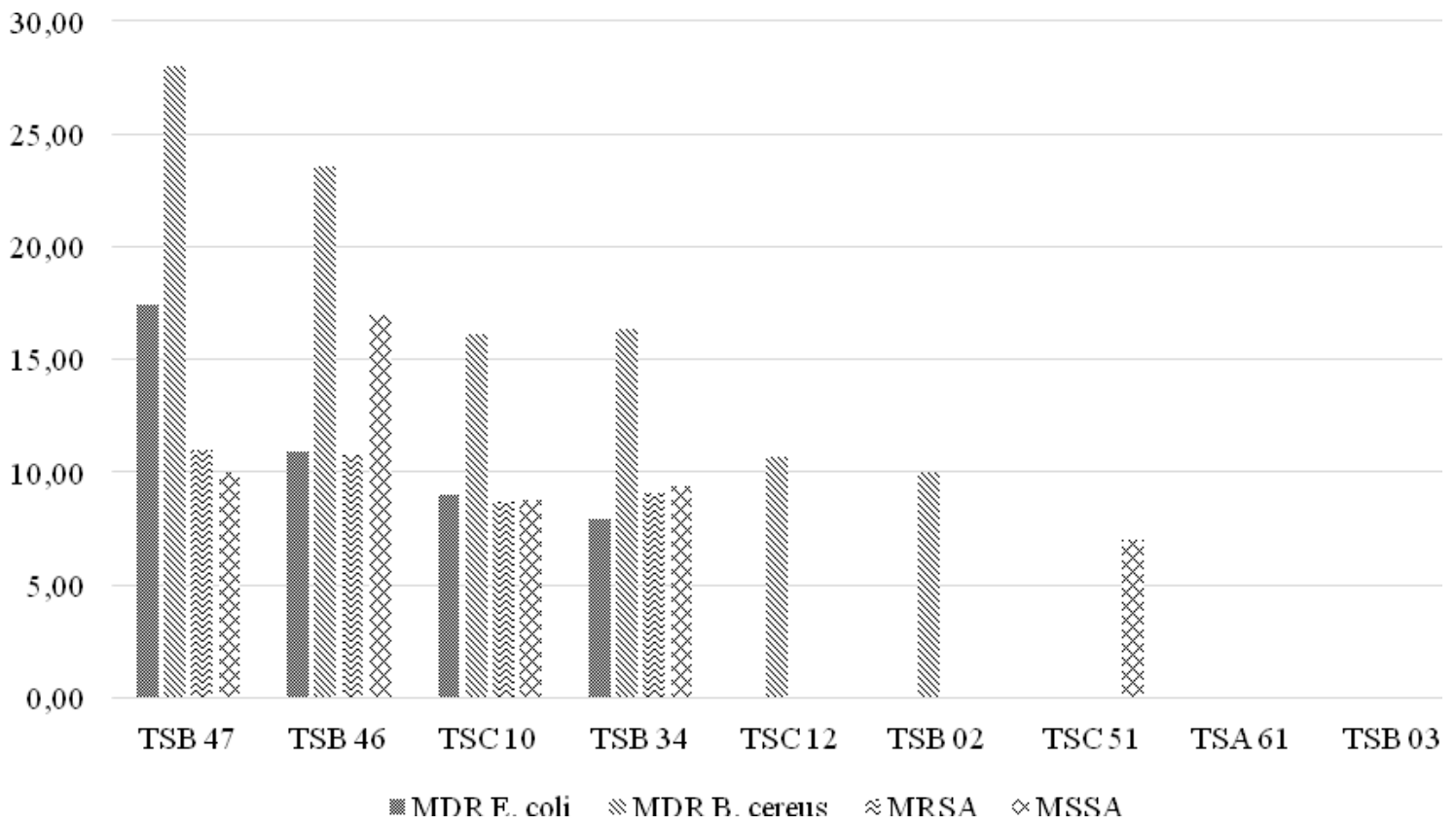

Figure 6. Anti-MDR activity from a crude extract of bacteria associated with tunicate $P$. aurata 


\section{REFERENCES}

Aiello A, Ernesto F, Concetta I, Carlo I, Paolo L, Marialuisa M, Rita S, Rocco V. 2011. Zorrimidazolone, a Bioactive Alkaloid from the NonIndigenous Mediterranean Stolidobranch Polyandrocarpa zorritensis. Mar Drugs 9: 1157-65. DOI: 10.3390/md9061157.

Ali AJ, Tamilselvi M. 2016. Ascidians in Coastal Water. Springer International Publishing, Switzerland. DOI: 10.1007/978-3-31929118-5.

Ankisetty S, Shabana IK, Bharathi A, Deborah G, Ikhlas AK, Marc S. 2013. Chlorinated Didemnins from the Tunicate Trididemnum solidum. Mar Drugs 11 (11): 4478-86. DOI: 10.3390/md11114478.

Arunachalam K, Appadorai RAJ. 2013. Antioxidant potential and biochemical evaluation of metabolites from the marine bacteria Virgibacillus sp. associated with the sponge Callyspongia diffusa. Free Radic Antioxid 3 (1): 47-51. DOI: 10.1016/j.fra.2013.04.004.

Asagabaldan MA, Ayuningrum D, Kristiana R, Sabdono A, Radjasa OK Trianto A. 2017. Identification and antibacterial activity of bacteria isolated from marine sponge Haliclona (Reniere) sp. against multidrug-resistant human pathogen. IOP Conference Series: Earth and Environmental Sciences. Vol. 55. :DOI: 10.1088/17551315/55/1/012019.

Ayuningrum D, Kristiana R, Asagabaldan MA, Nuryadi H, Sabdono A, Radjasa OK, Trianto A. 2017. Isolation, characterisation and antagonistic activity of bacteria symbionts Hardcoral pavona sp. isolated from Panjang Island, Jepara Against Infectious Multi-Drug Resistant (MDR) Bacteria. IOP Conference Series: Earth and Environmental Sciences. Vol. 55. DOI: DOI: 10.1088/17551315/55/1/012029.

Balouiri M, Sadiki M, Ibnsouda AK. 2016. Methods for in vitro evaluating antimicrobial activity: A review. J Pharm Anal 6: 71-79.

Benson H. 2001. Microbiological Applications A Laboratory Manual in General Microbiology, 8th ed. McGraw-Hill Companies, New York.

Bertanha CS, Januário AH, Alvarenga TA, Pimenta LP, Silva MLA Cunha WR, Pauletti PM. 2014. Quinone and hydroquinone metabolites from the ascidians of the Genus Aplidium. Mar Drugs 12 (6): 3608-3633. DOI: $10.3390 / \mathrm{md} 12063608$.

Campbell NA, Reece JB, Urry LA, Cain ML, Wasserman SA, Minorsky PV, Jackson RB. 2009. Campbell Biology, 9th ed. Pearson Education. San Francisco.

CDC [Centers for Disease Control and Prevention]. 2013. Antibiotic Resistance Threats. US Centers for Disease Control and Prevention, Washington, DC.

Chen L, Hu J, Xu J, Shao C, Wang G. 2018. Biological and chemical diversity of ascidian-associated microorganisms. Mar Drugs 743: 1 33. DOI: $10.3390 / \mathrm{md} 16100362$.

Dias PJ, Rocha R, Godwin S, Tovar-hernández MA, Delahoz MV Mckirdy S, Lestang PD, Mcdonald JI, Snow M. 2016. Investigating the cryptogenic status of the sea squirt Didemnum perlucidum (Tunicata, Ascidiacea ) in Australia based on a molecular study of its global distribution. Aquat Invas 11 (3): 239-45.

Edler MC, Fernandez AM, Lassota P, Ireland CM, Barrows LR. 2002 Inhibition of tubulin polymerization by vitilevuamide, a bicyclic marine peptide, at a site distinct from colchicine, the vinca alkaloids, and dolastatin. LR Biochem Pharmacol 63: 707-715.

Fattorusso E, Gerwick WH, Taglialatela-Scafati O. 2012. Handbook of Marine Natural Products. Springer, Dordrecht

Folmer O, Black M, Hoeh W, Lutz R, Vrijenhoek R. 1994. DNA primers for amplification of mitochondrial Cytochrome C Oxidase Subunit from diverse metazoan invertebrates. Mol Mar Biol Biotechnol 3 (5): 294-299.

Graevenitz A, Bucher C. 1983. Accuracy of the $\mathrm{KOH}$ and vancomycin tests in determining the gram reaction of non-enterobacterial rods. J Clin Microbiol 18 (4): 983-985

Halebian S, Harris B, Finegold SM, Rolfei RD. 1981. Rapid method that aids in distinguishing gram-positive from gram-negative anaerobic bacteria. RD J Clin Microbiol 13 (3): 444-48.

Kim, SK. 2015. Springer Handbook of Marine Biotechnology. SpringerVerlag, Berlin.

Kristiana R, Ayuningrum D, Asagabaldan MA, Nuryadi H, Sabdono A Radjasa OK, Trianto A. 2017. Isolation and partial characterization of bacteria activity associated with Gorgonian Euplexaura sp. agains methicillin-resistant Staphylococcus aureus (MRSA). IOP Conference
Series: Earth and Environmental Sciences. Vol. 55. DOI: 10.1088/1755-1315/55/1/012056.

Kott P. 2004. A New Species of Didemnum (Ascidiacea, Tunicata) from the Atlantic Coast of North America. Zootaxa 732: 1-10. www.mapress.com/zootaxa/.

Lambert G. 2005. Ecology and natural history of the protochordates. Can J Zool 83: 34-50. DOI: 10.1139/Z04-156.

Lestari ES, Severin JA, Filius PMG, Kuntaman K, Duerink DO, Hadi U, Wahjono H, Verbrugh HA. 2008. Antimicrobial Resistance among Commensal Isolates of Escherichia coli and Staphylococcus aureus in the Indonesian population inside and outside hospitals. Eur J Clin Microbiol Infect Dis 27 (1): 45-51. DOI: 10.1007/s10096-007-0396-z.

Lindquist N, Fenical W. 1990. Polycarpamines A-E, Antifungal disulfidesfrom the marine ascidian Polycarpa auzata. Tetrahedon Lett 31 (7): 2389-2392.

Lindquistl N, Fenical W, Duyne GDV, Clardy J. 1991. Isolation and structure determination of diazonamides $\mathrm{A}$ and $\mathrm{B}$, unsual cytotoxic metabolites from the marine ascidian Diazona chinensis. J Am Chem Soc 113 (6): 2303-2304

Magiorakos AP, Srinivasan A, Carey RB, Carmeli Y, Falagas ME, Giske CG, Harbarth S. 2012. Multidrug-resistant, extensively drug-resistant and pan-drug-resistant bacteria: an international expert proposal for interim standard definitions for acquired resistance. Clin Microbiol Infect18 (3): 268-81. DOI: 10.1111/j.1469-0691.2011.03570.x.

Mansson M, Gram L, Larsen TO. 2011. Production of bioactive secondary metabolite by marine Vibrionaceae. Mar Drugs 9: 1440-1468. DOI: 10.3390/md9091440.

Mohan G, Thangappanpillai AK, Ramasamy B. 2016. Antimicrobial activities of secondary metabolites and phylogenetic study of sponge endosymbiotic bacteria, Bacillus sp. at Agatti Island, Lakshadweep Archipelago. B Biotechnol Rep 11: 44-52. DOI: 10.1016/j.btre.2016.06.001

Mondol M, Mojid A, Shin HJ, Islam MT. 2013. Diversity of secondary metabolites from marine Bacillus species: Chemistry and Biological Activity. Mar Drugs 11 (8): 2846-2872. DOI: 10.3390/md11082846.

Nakazawa T, Xu J, Nishikawa T, Oda T, Fujita A, Ukai K, Mangindaan REP, Rotinsulu H, Kobayashi H, Namikoshi M. 2007. Lissoclibadins 4-7, polysulfur aromatic alkaloids from the Indonesian ascidian Lissoclinum cf. badium. J Nat Prod 70 (3): 439-442. DOI: 10.1021/np060593c

Paul VJ, Lindquist N, Fenical W. 1990. Chemical defenses of the tropical ascidian Atapozoa sp . and its nudibranch predators. Mar Ecol Prog Ser 59: 109-118.

Pham C, Weber H, Hartmann R, Wray V, Lin W, Lai D, Proksch P. 2013. New cytotoxic 1,2,4-thiadiazolealkaloids from the ascidian Polycarpa aurata. Org Lett 15 (9): 2230-2233

Penesyan A, Kjelleberg S, Egan S. 2010. Development of novel drugs from marine surface associated. Mar Drugs 8: 438-59. DOI: $10.3390 / \mathrm{md} 8030438$.

Rosenberg E, DeLong EF, Lory S, Stackebrandt E, Thompson F. 2014. The Prokaryotes, 4th ed. Springer-Verlag, Berlin.

Sakai R, Rinehart KL, Guan Y, Wang H. 1992. Additional antitumor ecteinascidins from a Caribbean tunicate: Crystal structures and activities in vivo. Proc Nat Acad Sci USA 89 (23): 11456-60. DOI: 10.1073/pnas.89.23.11456.

Schmidt EW, Donia MS, McIntosh JA, Fricke WF, Ravel J. 2012. Origin and variation of tunicate secondary metabolites. J Nat Prod 75 (2): 295-304. DOI: 10.1021/np200665k.Origin.

Severin JA, Lestari ES, Kloezen W, Toom NL, Mertaniasih NM, Kuntaman K, Purwanta M. 2012. Faecal carriage of extendedspectrum $\beta$-lactamase-producing Enterobacteriaceae among humans in Java, Indonesia, in 2001-2002. Trop Med Intl Health 17 (4): 45561. DOI: 10.1111/j.1365-3156.2011.02949.x.

Shenkar N, Gittenberger A, Lambert G, Rius M, Moreira Da Rocha R, Swalla B.J, Turon X. 2019. Ascidiacea World Database. Polycarpa aurata (Quoy \& Gaimard, 1834). World Register of Marine Species at: http://www.marinespecies.org/aphia.php? $\mathrm{p}=$ taxdetails\&id=251001 on 2019-01-10

Sibero MT, Bachtiarini TU, Trianto A, Lupita AH, Sari DP, Igarashi Y, Harunari E, Sharma AR, Radjasa OK, Sabdono A. 2018. Characterization of a yellow pigmented colar-associated bacterium exhibiting anti-bacterial activity against multidrug resistant (MDR) organism. Egyptian J Aquat Res, DOI: 10.1016/j.ejar.2018.11.007 
Stefaniak L, Lambert G, Gittenberger A, Zhang H, Lin S, Whitlatch RB. 2009. Genetic conspecificity of the worldwide populations of Didemnum vexillum Kott. 2009. Aquat Invas 4 (1): 29-44.

Wang W, Oda T, Fujita A, Mangindaan REP, Nakazawa T, Ukai K, Kobayashi H, Namikoshi m. 2007. Three new sulfur-containing alkaloids, polycarpaurines $\mathrm{A}, \mathrm{B}$, and $\mathrm{C}$, from Indonesian ascidian Polycarpa aurata. Tetrahedron 63: 409-412.
Weisburg WG, Barns SM, Pelletier DA, Lane DJ. 1991. 16S Ribosomal DNA amplification for phylogenetic study. J Bacteriol 173 (2): 697703.

Wessels M, Konig GM, Wright AD. 2001. New 4-methoxybenzoyl derivatives from the ascidian Polycarpa aurata 1. J Nat Prod 64 (12): 1556-58. DOI: 10.1021/np000570c.

WHO [World Health Organization]. 2014. Antimicrobial Resistance Global Report on Surveillance. World Health Organization, Geneva. 